\title{
Synthesis and Anti-Colon Cancer Activity of 1,2,4-Triazole Derivatives with Aliphatic S-Substituents
}

\author{
SADIQ AL-MANSURY ${ }^{1}$, ASIM A. BALAKIT ${ }^{2 *}$, FATIN FADHEL ALKAZAZZ ${ }^{3}$, \\ KAISER N. MADLUM ${ }^{4}$ and RANA A. GHALEB ${ }^{4}$
}

\author{
'Biochemistry \& Pharmacology Department, Veterinary Medicine College, \\ Al-Qasim Green University, Babylon, Iraq. \\ ${ }^{2}$ College of Pharmacy, University of Babylon, Babylon, Iraq. \\ ${ }^{3}$ College of Science, Department of Chemistry, Al-Mustansiyriah University, Baghdad, Iraq. \\ ${ }^{4}$ Department of Human Anatomy, College of Medicine, University of Babylon, Babylon, Iraq. \\ Corresponding author E-mail: asim_alsalehi@ hotmail.com
}

http://dx.doi.org/10.13005/ojc/350109

Received: November 16, 2018; Accepted: January 27, 2019)

\section{ABSTRACT}

A series of new 3-mercapto-1,2,4-triazole derivatives have been synthesized and characterized by FT-IR, ${ }^{1} \mathrm{H}$ NMR \& ${ }^{13} \mathrm{C}$ NMR spectrophotometric techniques. The target compounds are designed as analogues for the anti-cancer agent Combretastatin A-4 with different aliphatic side substituents. The anticancer activity of the synthesized compounds was studied against colon cancer cell line SW480 using the crystal violet cytotoxicity assay. The results showed that all the synthesized compounds have growth inhibitive effect on the cancer cells with different inhibition levels. Compound 5 a with -SMe group was found to be the most active one with $77.4 \%$ cell growth inhibition and $10 \mu \mathrm{M} \mathrm{IC}{ }_{50}$ value, it was also found to have relatively low cytotoxicity when tested against MDCK normal cells. The antioxidant activity of the synthesized compounds was tested using DPPH assay against ascorbic acid as a reference antioxidant agent at 50 $\mu \mathrm{M}$. Compound 4 showed highest antioxidant activity with DPPH radical scavenging capacity of $71 \%$.

Keywords: Triazole, Colon cancer, Anticancer, Antioxidants, SW480.

\section{INTRODUCTION}

Cancer is considered as the second lethal disease worldwide ${ }^{1}$, colon cancer is the third most common type of cancer around the world and one of the leading reasons of cancer-related deaths. ${ }^{2}$ The design and synthesis of anticancer agents is an interesting research area in which scientists are endeavoring to develop synthetic or natural compounds that can contribute in the treatment of cancer and help patients to be cured of this life-threatening disease. ${ }^{3}$ There is a very

This is an Open Access article licensed under a Creative Commons license: Attribution 4.0 International (CC- BY). Published by Oriental Scientific Publishing Company @ 2018 
broad spectrum of natural compounds which are considered as anticancer agents ${ }^{4}$ among them combretastatin A 4 (CA-4) which is natural product isolated from the South African tree; Combretum caffrum Kuntze (Combretaceae). ${ }^{5}$ The anticancer activity of CA-4 is attributed to the inhibition of tubulin polymerization by binding to the colchicine binding site. ${ }^{6}$ The simplicity of the structure of CA-4 and its remarkable anticancer efficacy make its structure a fundamental part of wide range of synthetic anticancer agents which are considered as combretastatin A-4 analogues. ${ }^{7-9}$ Based on the structure-activity relationship (SAR) studies, it is reported the CA-4 analogues must have fundamental structural requirements for the optimal activity, the molecule must have 3,4,5-trimethoxyphenyl and 4-methoxyphenyl groups attached to two adjacent atoms (bridge), the two groups must be in cis-olefin configuration. ${ }^{10,11}$

A great attention has been devoted to the 1,2,4-triazol derivatives because of their biological activities, particularly sulfur-containing ones found to have a broad-spectrum of biological activities such as herbicidal ${ }^{12}$, anticancer ${ }^{13}$, antidepressant ${ }^{14}$, antimicrobial $^{15}$, antifungal ${ }^{16}$, analgesic/antiinflammatory ${ }^{17}$, antiviral ${ }^{18}$, and antioxidant. ${ }^{19}$ Many studies have shown that the pharmacological activities of 1,2,4-triazole and their derivatives due to existence of the1,2,4-triazole nucleus..$^{20}$ Some of compounds with triazole ring are reported as potent anticancer CA-4 analogues. ${ }^{21}$ The presence of S-linkers in the structure improve some druglike parameters such as decreasing lipophilicity, increasing water solubility, and offering good hydrogen bond acceptors. ${ }^{22}$

Antioxidants are compounds that have the ability to reduce the oxidative stress by inhibiting the oxidation process leading to preventing the cell death resulting from generated free radicals. ${ }^{23}$ The excessive release of free radicals is intimately related to cancer disease ${ }^{24}$, thereby antioxidants can contribute in fighting this deadly disease. There is huge number of both natural and synthetic compounds that are investigated for their antioxidant capacity. ${ }^{25,} 26$

In the present work we report the design and synthesis of new 1,2,4-triazole derivatives with aliphatic substituents attached to the sulfur group, the new compounds are designed to meet the structural requirements of the highest expected anticancer activity of CA-4 analogues to be tested as anticancer agents against colon cancer cell line SW480. The antioxidant capacity of the synthesized compounds is also studied.

\section{MATERIAL AND METHODS}

\section{General}

Chemicals and reagents were purchased from commercial sources and used without any further purification. ${ }^{1} \mathrm{H}(400 \mathrm{MHz})$ and ${ }^{13} \mathrm{C}$ NMR $(100$ $\mathrm{MHz}$ ) spectra were recorded in $\mathrm{CDCl}_{3}$ or DMSO$\mathrm{d}_{6}$ on a Bruker Bio Spin $400 \mathrm{MHz}$ spectrometer. Chemical shifts $\delta(\mathrm{ppm})$ are reported relative to tetramethylsilane (TMS). IR spectra were recorded on a Tensor II, Bruker-Optics FT-IR spectrophotometer as $\mathrm{KBr}$ discs. Melting points were measured using Stuart SMP10 apparatus. Column chromatography was carried out using silica gel $200-300$ Mesh. 3,4,5 Trimethoxybenzohydrazide was synthesized according to literature procedure. ${ }^{27}$

Synthesis: 4-(4-Methoxyphenyl)-5-(3,4,5trimethoxyphenyl)-4H-1,2,4-triazole-3-thiol (4):

4-Methoxyphenyl isothiocyanate (1.65 $\mathrm{gm}, 10 \mathrm{mmol}$ ) was added to a solution of $3,4,5-$ trimethoxybenzohydrazide $(2.263 \mathrm{~g}, 10 \mathrm{mmol})$ in ethanol $(30 \mathrm{~mL})$, the mixture was then subjected to reflux conditions for $4 \mathrm{~h}$ then was cooled at room temperature. The formed solid was collected by filtration and washed withethanol and derided. Then the solid product was dissolved in $20 \mathrm{~mL}$ of $2 \mathrm{~N} \mathrm{NaOH}$ and refluxed for 4 hours. The mixture was left to cool to room temperature and then filtrated; the filtrate was acidified with $10 \%$ hydrochloric acid. The participated solid was filtrated off, washed with cold water.

Light-yellow solid; yield, 81\%; m.p. 253$255^{\circ} \mathrm{C}$; FT-IR: 3091-2931 (C-H, aromatic), 2829 (C-H, aliphatic), $2754(\mathrm{SH}), 1606(\mathrm{C}=\mathrm{N}), 1591(\mathrm{C}=\mathrm{C}) ;{ }^{1} \mathrm{H}$ $\operatorname{NMR}\left(400 \mathrm{MHz}, \mathrm{DMSO}-\mathrm{d}_{6}\right) \delta: 3.57\left(\mathrm{~s}, 6 \mathrm{H}, 2 \mathrm{xOCH}_{3}\right)$, $3.65\left(\mathrm{~s}, 3 \mathrm{H}, \mathrm{OCH}_{3}\right), 3.80\left(\mathrm{~s}, 3 \mathrm{H}, \mathrm{OCH}_{3}\right), 6.61(\mathrm{~s}, 2 \mathrm{H}$, Aromatic), 7.07 (d, $J=8.8 \mathrm{~Hz}, 2 \mathrm{H}$, Aromatic), 7.30 (d, $J=8.8 \mathrm{~Hz}, 2 \mathrm{H}$ Aromatic), 14.07 (br, $1 \mathrm{H}, \mathrm{SH}$ ). ${ }^{13} \mathrm{C}$ NMR (100-MHz, DMSOd ${ }_{6}$ ) d: 56.0, 56.2 (2C), 60.5, $106.28(2 \mathrm{C}), 115.0(2 \mathrm{C}), 121.3,127.8,130.5$ (2C), 139.4, 150.7, 153.0 (2C), 160.1, 169.3. 
General procedure for the synthesis of target compounds (5a-j)

To the solution of $4(0.373 \mathrm{gm}, 1 \mathrm{mmol})$ in $20 \mathrm{ml}$ of $50 \%$ aqueous 2-propanol, $\mathrm{NaOH}(0.04 \mathrm{~g}$, $1.5 \mathrm{mmol}$ ) was added, the mixture was stirred for $5 \mathrm{~min}$ then appropriate alkyl halide $(1.1 \mathrm{mmol})$ was added to. The reaction mixture was refluxed for 8 hours. The reaction progress was monitored by TLC, after completion the 2-propanol was evaporated under reduced pressure and the product was extracted by chloroform, solvent was evaporated to give the crude solid product which was washed with hexane and then purified by column chromatography. The melting points, eluents and $\mathrm{R} f$ values of the synthesized compounds are shown in Table 1.

Table 1: Melting points, eluents and Rf values of $4,5 a-j$

\begin{tabular}{cccc}
\hline Compound & m.p. ${ }^{\circ} \mathrm{C}$ & $\begin{array}{c}\text { Eluent(n-hexane: } \\
\text { ethyl acetate) }\end{array}$ & $\begin{array}{c}\text { Rf(n-hexane: ethyl } \\
\text { acetate; } 1.5: 2.5)\end{array}$ \\
\hline 4 & $253-255$ & -- & 0.54 \\
$5 \mathrm{a}$ & $102-103$ & $1: 2$ & 0.07 \\
$5 \mathrm{~b}$ & $80-81$ & $1: 2$ & 0.14 \\
$5 \mathrm{c}$ & $104-106$ & $1: 1.5$ & 0.285 \\
$5 \mathrm{~d}$ & $106-108$ & $1: 1.5$ & 0.357 \\
$5 \mathrm{e}$ & $94-96$ & $1: 1$ & 0.297 \\
$5 f$ & $112-113$ & $1: 1.5$ & 0.214 \\
$5 \mathrm{~g}$ & $93-95$ & $1: 1.5$ & 0.2 \\
$5 \mathrm{~h}$ & $90-92$ & $1: 1.5$ & 0.33 \\
$5 \mathrm{i}$ & $80-82$ & $1: 1$ & 0.19 \\
$5 \mathrm{j}$ & $109-110$ & $1: 2$ & 0.13 \\
\hline
\end{tabular}

4-(4-Methoxyphenyl)-3-(methylthio)-5-(3,4,5trimethoxyphenyl)-4H-1,2,4-triazole (5a)

Yellow solid, yield, 84\%; FT-IR: 3090-2928 (C-H, aromatic), 2829 (C-H, aliphatic), $1607(\mathrm{C}=\mathrm{N})$, $1585(\mathrm{C}=\mathrm{C}) ;{ }^{1} \mathrm{H}$ NMR (400 MHz, $\mathrm{CDCl}_{3}$ ) $\delta: 2.7$ (s, 3H, $\left.\mathrm{SCH}_{3}\right), 3.63\left(\mathrm{~s}, 6 \mathrm{H}, 2 \times \mathrm{OCH}_{3}\right), 3.82\left(\mathrm{~s}, 3 \mathrm{H}, \mathrm{OCH}_{3}\right)$, $3.86\left(\mathrm{~s}, 3 \mathrm{H}, \mathrm{OCH}_{3}\right), 6.69$ (s, 2H, Aromatic), 7.08 (d, $J=8.9 \mathrm{~Hz}, 2 \mathrm{H}$, Aromatic), 7.20 (d, $J=8.9 \mathrm{~Hz}, 2 \mathrm{H}$, Aromatic). ${ }^{13} \mathrm{C} \mathrm{NMR}\left(100 \mathrm{MHz}, \mathrm{CDCl}_{3}\right) \delta: 14.64,55.69$, 55.93(2C), 60.8, 105.37 (2C), 115.18 (2C), 121.3, 126.9(2C), 128.7, 139.8, $153(2 \mathrm{C}), 154.1,154.8,160.6$

3-(Ethylthio)-4-(4-methoxyphenyl)-5-(3,4,5trimethoxyphenyl)-4H-1,2,4-triazole (5b)

Yellow solid, yield 82\%; FT-IR: 3091-2931

(C-H, aromatic), 2829 (C-H, aliphatic), $1607(\mathrm{C}=\mathrm{N})$, $1587(\mathrm{C}=\mathrm{C}) ;{ }^{1} \mathrm{H}$ NMR (400 MHz, $\mathrm{CDCl}_{3}$ ) $\delta: 1.43$ (t, $J=7.4 \mathrm{~Hz}, 3 \mathrm{H}, \mathrm{SCH}_{2} \mathrm{CH}_{3}$ ), 3.3 (q, J = 7.3 Hz, $2 \mathrm{H}, \mathrm{SCH}_{2} \mathrm{CH}_{3}$ ), 3.64 (s, $\left.6 \mathrm{H}, 2 \times \mathrm{OCH}_{3}\right), 3.82(\mathrm{~s}, 3 \mathrm{H}$, $\left.\mathrm{OCH}_{3}\right), 3.86$ (s, 3H, $\left.\mathrm{OCH}_{3}\right), 6.69$ (s, 2H, Aromatic), 7.03 (d, $J=8.9 \mathrm{~Hz}, \mathrm{~d}, 2 \mathrm{H}$, Aromatic), 7.21 (d, $J=$
7.7 Hz, 2H, Aromatic). $\left.{ }^{13} \mathrm{C} \mathrm{NMR} \mathrm{(100} \mathrm{MHz,} \mathrm{CDCl}_{3}\right)$ $\delta: 14.7,26.8,55.69-55.91(3 \mathrm{C}), 60.88,105.3(2 \mathrm{C})$, 115.9 (2C), 121.9, 127.0, 128.7(2C) 138.8, 144.5, $153.0(2 \mathrm{C}), 154.6,160.5$.

3-(Butylthio)-4-(4-methoxyphenyl)-5-(3,4,5trimethoxyphenyl)-4H-1,2,4-triazole (5c)

Yellow crystal, yield 78\%; FT-IR: $3001(\mathrm{C}-\mathrm{H}$, aromatic), 2958 (C-H, aliphatic), $1609(\mathrm{C}=\mathrm{N}), 1588$ $(\mathrm{C}=\mathrm{C}) ;{ }^{1} \mathrm{H}$ NMR $\left(400 \mathrm{MHz}, \mathrm{CDCl}_{3}\right) 0.91$ (t, $J=7.3$ $\mathrm{Hz}, 3 \mathrm{H}, \mathrm{SCH}_{2} \mathrm{CH}_{2} \mathrm{CH}_{2} \mathrm{CH}_{3}$ ), 1.43 (sext, $J=7.3 \mathrm{~Hz}$, $\left.2 \mathrm{H}, \mathrm{SCH}_{2} \mathrm{CH}_{2} \mathrm{CH}_{2} \mathrm{CH}_{3}\right), 1.7$ (p, J=7.4 Hz, $2 \mathrm{H}, \mathrm{SCH}_{2}$ $\mathrm{CH}_{2} \mathrm{CH}_{2} \mathrm{CH}_{3}$ ), $3.2\left(\mathrm{t}, \mathrm{J}=7.3 \mathrm{~Hz}, 2 \mathrm{H}, \mathrm{SCH}_{2} \mathrm{CH}_{2} \mathrm{CH}_{2}\right.$ $\left.\mathrm{CH}_{3}\right), 3.64\left(\mathrm{~s}, 6 \mathrm{H}, 2 \times \mathrm{OCH}_{3}\right), 3.83\left(\mathrm{~s}, 3 \mathrm{H}, \mathrm{OCH}_{3}\right)$, $3.88\left(\mathrm{~s}, 3 \mathrm{H}, \mathrm{OCH}_{3}\right), 6.69$ (s, 2H, Aromatic), 7.08 (d, $J=8.8 \mathrm{~Hz}, 2 \mathrm{H}$, Aromatic), 7.19 (d, $J=8.8 \mathrm{~Hz}$, $2 \mathrm{H}$, Aromatic). ${ }^{13} \mathrm{C}$ NMR (100 MHz, $\mathrm{CDCl}_{3}$ ) $\delta: 13.5$, 21.8, 31.35, 32.2, 55.68-55.9 (3C), 60.2, $105.3(2 \mathrm{C})$, 115.0(2C), 121.9, 127.1, 128.8 (2C), 139.1, 153, 153.5(2C), 154.6, 160.5.

3-(Hexylthio)-4-(4-methoxyphenyl)-5-(3,4,5trimethoxyphenyl)-4H-1,2,4-triazole (5d)

White solid, yield 87\%; FT-IR: $3110(\mathrm{C}-\mathrm{H}$, aromatic), $2836(\mathrm{C}-\mathrm{H}$, aliphatic), $1608(\mathrm{C}=\mathrm{N})$, $1588(\mathrm{C}=\mathrm{C}) ;{ }^{1} \mathrm{H}$ NMR (400 $\left.\mathrm{MHz} \mathrm{CDCl}_{3}\right) \delta: 0.87$ (t, $J=6.7 \mathrm{~Hz}, 3 \mathrm{H}, \mathrm{S}\left(\mathrm{CH}_{2}\right) 5 \mathrm{CH}_{3}$ ), 1.30 (sext, $J=$ $\left.4.5 \mathrm{~Hz}, 2 \mathrm{H}, \mathrm{S}\left(\mathrm{CH}_{2}\right)_{4} \mathrm{CH}_{2} \mathrm{CH}_{3}\right), 1.42(\mathrm{p}, J=7.2 \mathrm{~Hz}$, $\left.4 \mathrm{H}, \mathrm{S}\left(\mathrm{CH}_{2}\right)_{2} \mathrm{CH}_{2} \mathrm{CH}_{2} \mathrm{CH}_{2} \mathrm{CH}_{3}\right), 1.64(\mathrm{p}, J=7.5 \mathrm{~Hz}$, $\left.2 \mathrm{H}, \mathrm{SCH}_{2} \mathrm{CH}_{2}\left(\mathrm{CH}_{2}\right)_{3} \mathrm{CH}_{3}\right), 3.26$ (t, $J=7.6 \mathrm{~Hz} 2 \mathrm{H}$, $\left.\mathrm{SCH}_{2}\left(\mathrm{CH}_{2}\right)_{4} \mathrm{CH}_{3}\right), 3.64\left(\mathrm{~s}, 6 \mathrm{H}, 2 \times \mathrm{OCH}_{3}\right), 3.8(\mathrm{~s}, 3 \mathrm{H}$, $\mathrm{OCH}_{3}$ ), 3.88 (s, $\left.3 \mathrm{H}, \mathrm{OCH}_{3}\right), 6.69$ (s, 2H, Aromatic), 7.08 (d, $J=8.5 \mathrm{~Hz}, 2 \mathrm{H}$, Aromatic), 7.2 (d, $J=8.9$ $\mathrm{Hz}, 2 \mathrm{H}$, Aromatic). $\left.{ }^{13} \mathrm{C} \mathrm{NMR} \mathrm{(100} \mathrm{MHz,} \mathrm{CDCl}_{3}\right) \delta$ : 13.9, 22.5, 28.4, 29.3, 31.2, 32.2, 55.6, 55.9(2C), $60.8,105.33(2 \mathrm{C}), 115.03(2 \mathrm{C}), 121.8,127.1,128.8$ (2C), 139.1, 153 (2C), 153.5, 154.6, 160.5.

3-(Isobutylthio)-4-(4-methoxyphenyl)-5-(3,4,5trimethoxyphenyl)-4H-1,2,4-triazole (5e)

White solid, yield 78\%; FT-IR: 3003 (C-H, aromatic), 2867 (C-H, aliphatic), 1606 $(\mathrm{C}=\mathrm{N}), 1588(\mathrm{C}=\mathrm{C}) ;{ }^{1} \mathrm{H}$ NMR (400 $\left.\mathrm{MHz} \mathrm{CDCl}_{3}\right)$ $\delta: 1.01\left(\mathrm{~d}, J=6.6 \mathrm{~Hz}, 6 \mathrm{H}, \mathrm{SCH}_{2} \mathrm{CH}\left(\mathrm{CH}_{3}\right)_{2}\right), 2.02$ $\left(\mathrm{m}, 1 \mathrm{H}, \mathrm{SCH}_{2} \mathrm{CH}\left(\mathrm{CH}_{3}\right)_{2}\right), 3.18(\mathrm{~d}, \mathrm{~J}=6.8 \mathrm{~Hz}, 2 \mathrm{H}$, $\left.\mathrm{SCH}_{2} \mathrm{CH}\left(\mathrm{CH}_{3}\right)_{2}\right), 3.6\left(6 \mathrm{H}, 2 \times \mathrm{OCH}_{3}\right), 3.83(\mathrm{~s}, 3 \mathrm{H}$, $\left.\mathrm{OCH}_{3}\right), 3.89\left(\mathrm{~s}, 3 \mathrm{H}, \mathrm{OCH}_{3}\right), 6.69$ (s, $2 \mathrm{H}$ Aromatic), 7.08 (d, $J=8.7 \mathrm{~Hz}, 2 \mathrm{H}$, Aromatic), 7.19 (d, $J=8.7$ $\mathrm{Hz}, 2 \mathrm{H}, \mathrm{ArH} \mathrm{B}) .{ }^{13} \mathrm{C}$ NMR (100 MHz, $\mathrm{CDCl}_{3}$ ) $\delta: 21.8$ (2C), 26.45, 40.9, 55.68 (3C), 60.87, 105.3(2C), $115.03(2 \mathrm{C}), 121.9,127.1,128.8(2 \mathrm{C}), 139.1,153.0$ (2C), 153.7, 154.58, 160.5 . 
3-(Allylthio)-4-(4-methoxyphenyl)-5-(3,4,5trimethoxyphenyl)-4H-1,2,4-triazole (5f)

Yellow solid, yield 87\%; FT-IR: $3091(\mathrm{C}-\mathrm{H}$, aromatic), $2838(\mathrm{C}-\mathrm{H}$, aliphatic), $1607(\mathrm{C}=\mathrm{N})$, $1585(\mathrm{C}=\mathrm{C})$; ${ }^{1} \mathrm{H}$ NMR $\left(400 \mathrm{MHz}, \mathrm{CDCl}_{3}\right)$ 8: 3.63 $\left(\mathrm{s}, 6 \mathrm{H}, 2 \times \mathrm{OCH}_{3}\right), 3.82\left(\mathrm{~s}, 3 \mathrm{H}, \mathrm{OCH}_{3}\right), 3.85$ $\left(\mathrm{s}, 3 \mathrm{H}, \mathrm{OCH}_{3}\right), 3.87\left(\mathrm{~d}, \mathrm{~J}=7.1 \mathrm{~Hz}, 2 \mathrm{H}, \mathrm{SCH}_{2} \mathrm{CH}=\mathrm{CH}_{2}\right.$ ), $5.12\left(\mathrm{~d}, \mathrm{~J}=9.97 \mathrm{~Hz}, 1 \mathrm{H}, \mathrm{SCH}_{2} \mathrm{CH}=\mathrm{CH}_{2}\right), 5.23$ (d, J=9.2 $1 \mathrm{H}, \mathrm{SCH}_{2} \mathrm{CH}=\mathrm{CH}_{2}$ ), 5.94 (q, J=7.4 Hz, $1 \mathrm{H}, \mathrm{SCH}_{2} \mathrm{CH}=\mathrm{CH}_{2}$ ), 6.69 (s, 2H, Aromatic), 7.08 (d, $J=8.8 \mathrm{~Hz}, 2 \mathrm{H}$, Aromatic), $7.19(\mathrm{~d}, J=8.7 \mathrm{~Hz}$, $2 \mathrm{H}$, Aromatic). ${ }^{13} \mathrm{C} \mathrm{NMR}\left(100 \mathrm{MHz}, \mathrm{CDCl}_{3}\right) \delta: 35.38$, 55.7-55.917 (3C), 60.89, 105.33(2C), 115.03(2C), 119.0, 121.9, 127.1, 128.8 (2C), 132.65, 139.1, 152.7, $153(2 \mathrm{C}), 154.7,160.5$.

3-(Isopropylthio)-4-(4-methoxyphenyl)-5-(3,4,5trimethoxyphenyl)-4H-1,2,4-triazole (5g)

White solid, yield 83\%; FT-IR: $2999(\mathrm{C}-\mathrm{H}$, aromatic), 2961 (C-H, aliphatic), $1607(\mathrm{C}=\mathrm{N}), 1586$ $(\mathrm{C}=\mathrm{C}) ;{ }^{1} \mathrm{H}$ NMR $\left(400 \mathrm{MHz}, \mathrm{CDCl}_{3}\right) \delta: 1.4$ (dd, $J=$ $\left.6.7 \mathrm{~Hz}, 6 \mathrm{H}, \mathrm{CH}\left(\mathrm{CH}_{3}\right)_{2}\right), 3.6\left(\mathrm{~s}, 6 \mathrm{H}, 2 \times \mathrm{OCH}_{3}\right), 3.82$ (s, 3H, OCH $\mathrm{OCH}_{3}$ ) $3.86\left(\mathrm{~s}, 3 \mathrm{H}, \mathrm{OCH}_{3}\right), 3.93$ (sep, J=6.6 $\mathrm{Hz}, 1 \mathrm{H}, \mathrm{CH}\left(\mathrm{CH}_{3}\right)_{2}, 6.69$ (s, 2H, Aromatic), 7.0 (d, J=8.9 $\mathrm{Hz}, 2 \mathrm{H}$, Aromatic), 7.16 (d, $J=8.8 \mathrm{~Hz}, 2 \mathrm{H}$, Aromatic). ${ }^{13} \mathrm{C} \mathrm{NMR}\left(100 \mathrm{MHz}, \mathrm{CDCl}_{3}\right) \delta: 23.5(2 \mathrm{C}), 38.6,55.68-$ $55.9(3 \mathrm{C}), 60.8,105.3(2 \mathrm{C}), 115.03(2 \mathrm{C}), 121.9,127.2$, 128.9 (2C), 139.1, 152.3, 153 (2C), 154.4, 160.4.

\section{3-(Cyclohexylthio)-4-(4-methoxyphenyl)-5-(3,4,5- trimethoxyphenyl)-4H-1,2,4-triazole (5h)}

White solid, yield 81\%; FT-IR: 2936 (C-H, aromatic), $2848(\mathrm{C}-\mathrm{H}$, aliphatic), $1606(\mathrm{C}=\mathrm{N}), 1589$ $(\mathrm{C}=\mathrm{C})$; ${ }^{1} \mathrm{H}$ NMR $\left(400 \mathrm{MHz}, \mathrm{CDCl}_{3}\right)$ d: $1.2-2.13$ (m, 11H, cyclohexyl), $3.63\left(\mathrm{~s}, 6 \mathrm{H}, 2 \times \mathrm{OCH}_{3}\right), 3.81(\mathrm{~s}$, $\left.3 \mathrm{H}, \mathrm{OCH}_{3}\right), 3.85\left(\mathrm{~s}, 3 \mathrm{H}, \mathrm{OCH}_{3}\right), 6.68(\mathrm{~s}, 2 \mathrm{H}$, Aromatic), $7.0(\mathrm{~d}, J=7.7 \mathrm{~Hz}, 2 \mathrm{H}$, Aromatic), 7.17 (d, $J=7.9 \mathrm{~Hz}$, $2 \mathrm{H}$, Aromatic). ${ }^{13} \mathrm{C}$ NMR (100 MHz, $\left.\mathrm{CDCl}_{3}\right)$ : 25.57 , 25.8, 33.4, 33.47, 46.48, 55.68, 55.8-55.9 (3C), 60.89, 105.33(2C), $115.0(2 \mathrm{C}), 121.9,127.1,128.8(2 \mathrm{C})$, 139.1, 152.6, 152.9 (2C), 154.4, 160.4.

4-(4-Methoxyphenyl)-3-((oxiran-2-yImethyl)thio)5-(3,4,5-trimethoxyphenyl)-4H-1,2,4-triazole (5i)

Light yellow solid, yield 79\%; FT-IR: 2936 (C-H, aromatic), 2844 (C-H, aliphatic), $1601(\mathrm{C}=\mathrm{N})$, $1585(\mathrm{C}=\mathrm{C})$; ${ }^{1} \mathrm{H}$ NMR (400 MHz, DMSO-d $\left.\mathrm{d}_{6}\right) \delta: 3.57$ (s, $\left.6 \mathrm{H}, 2 \times \mathrm{OCH}_{3}\right), 3.65\left(\mathrm{~s}, 3 \mathrm{H}, \mathrm{OCH}_{3}\right), 3.79(\mathrm{~s}$, $\left.3 \mathrm{H}, \mathrm{OCH}_{3}\right), 3.8\left(\mathrm{q}, J=6.5 \mathrm{~Hz}, 2 \mathrm{H}, \mathrm{CH}_{2}\right.$ ring), 3.9 (q, $J=5.2 \mathrm{~Hz}, 1 \mathrm{H}, \mathrm{CH}$ ring), 4.16 (q, $J=5.3 \mathrm{~Hz}, 2 \mathrm{H}$, $\left.\mathrm{SCH}_{2}-\right), 6.57$ (s, 2H, Aromatic), $7.08(\mathrm{~d}, J=8.8 \mathrm{~Hz}$,
$2 \mathrm{H}$, Aromatic), 7.29 (d, $J=8.77 \mathrm{~Hz}, 2 \mathrm{H}$, Aromatic). ${ }^{13} \mathrm{C}$ NMR $\left(100 \mathrm{MHz}, \mathrm{DMSO}-\mathrm{d}_{6}\right)$ 8: 48.03, 49.07, 56.03, 56.18, 60.6, 61.7, 68.8, 105.6 (2C), 115.13 (2C), 121.5, 127.1, 129.9 (2C), 139.2, 144.35, 153.1(2C), 153.8, 159.89 .

Methyl2-((4-(4-methoxyphenyl)-5-(3,4,5trimethoxyphenyl)-4H-1,2,4-triazol-3-yl)thio) acetate $(5 \mathrm{j})$

Brown solid, yield 83\%, FT-IR: 3069-2935 (C-H, aromatic), 2961 (C-H, aliphatic), $1735(-\mathrm{C}=\mathrm{O})$, $1610(\mathrm{C}=\mathrm{N}), 1587(\mathrm{C}=\mathrm{C})$; ${ }^{1} \mathrm{H}$ NMR $(400 \mathrm{MHz}$, $\left.\mathrm{CDCl}_{3}\right) \delta: 3.6\left(\mathrm{~s}, 6 \mathrm{H}, 2 \times \mathrm{OCH}_{3}\right), 3.77\left(\mathrm{~s}, 3 \mathrm{H}, \mathrm{OCH}_{3}\right.$, ester), $3.82\left(\mathrm{~s}, 3 \mathrm{H}, \mathrm{OCH}_{3}\right), 3.86\left(\mathrm{~s}, 3 \mathrm{H}, \mathrm{OCH}_{3}\right), 4.15$ $\mathrm{s}, 2 \mathrm{H},-\mathrm{SCH}_{2} \mathrm{COOCH}_{3}, 6.69$ (s, 2H, Aromatic), 7.02 (d, $J=6.9 \mathrm{~Hz}, 2 \mathrm{H}$, Aromatic), $7.22(\mathrm{~d}, J=7,2 \mathrm{~Hz}, 2 \mathrm{H}$, Aromatic); ${ }^{13} \mathrm{C}$ NMR $\left(100 \mathrm{MHz}, \mathrm{CDCl}_{3}\right) \delta: 34.2,52.9$, 55.7- 56.9(3C), 60.9, 105.32 (2C), 115.22(2C), 121.5, 126.6, 128.7(2C), 139.2, 151.4, 153.8 (2C), 154.9, $160.7,168.8(\mathrm{C}=\mathrm{O})$.

\section{Culturing of SW480 and MDCK Cell Lines}

The stock human colon cancer (SW480) and Madin-Darby Canine Kidney (MDCK) cell lines were obtained from the Cancer Research Lab. and Cell Culture at the College of Medicine, University of Babylon. The cells were grown as monolayer and maintained as an exponentially growth phase in Dulbecco's modified Eagle's medium (DMEM) supplemented with $5 \%$ heat inactivated fetal bovine serum (FBS) and 1\% penicillin-streptomycin (GIBCO $尺$ ) in tissue culture flask and incubated at $37^{\circ} \mathrm{C}$ in humidified atmosphere containing $5 \% \mathrm{CO}_{2}$. The cells were maintained by the replacement of fresh medium.

\section{Anticancer activity}

The test compounds were dissolved in acetone at concentration of $10 \mathrm{mM}$ and diluted with DMEM to get the desired concentrations for the treatments of cell lines. Mixture of acetone: DMEM (200 $\mu \mathrm{l}$, with the same ratios used in the test samples) was added to the negative control samples, the added volumes of acetone have no any effect on the cell growth when compared with the positive control samples, accordingly a normalized control was depended in the study.

Overnight cultures of the cells grown in $25 \mathrm{~cm} 2$ tissue culture flask were examined under inverted microscope. Cells were detached using trypsin, washed twice by adding $5 \mathrm{ml}$ of 
PBS and centrifugation at $1500 \mathrm{rpm}$ for 5 minutes. These exponentially growing cells were seeded in 96-well plates (5000 cells/well) and incubated at $37^{\circ} \mathrm{C}$ for $24 \mathrm{~h}$ for attachment. Then, the media was removed and $200 \mu \mathrm{l}$ of fresh medium containing the test compound at different concentrations were added to each well in four replicates and incubated at $37^{\circ} \mathrm{C}$ for 48 hours. The wells were then washed by adding $200 \mu$ l of PBS for each well, left for $5 \mathrm{~min}$ and removed by sterile pasture pipet. This process was repeated twice. The wells were treated with $100 \mu$ of crystal violate solution for 10 minutes. The dye was discarded and the plates were washed with distilled water three times. The plates were left to dry at room temperature, then the absorbance was measured at $570 \mathrm{~nm}$ by using plate reader (Human). The inhibition percentage was calculated using the following formula:27,3

\%inhibition $=\left[(\text { Abs control-Abs samples)/(Abs control ) }]^{\star} 100\right.$

\section{Determination of $\mathrm{IC}_{50}$ Value}

The $I C_{50}$ of $5 \mathrm{a}$ was determined by treating the cancer cell line (SW480) with different concentrations of $5 \mathrm{a}$ to find out the concentration that results a $50 \%$ cell growth inhibition. The $\mathrm{IC}_{50}$ value was calculated by using SigmaPlot version 12 software.

\section{Antioxidant activity}

The DPPH radical scavenging protocol was applied to assess the scavenging activity of synthetized compounds. Solutions of the test compounds $(0.005$ $\mathrm{M}$ in DMSO) were prepared, then, $50 \mu \mathrm{M}$ solutions were prepared by dilution with methanol. Ascorbic acid $(50 \mu \mathrm{M})$ was also prepared in the same manner. In test tube, $3 \mathrm{~mL}$ of the test compound were mixed with $50 \mu \mathrm{L}$ of DPPH (0.004 M in methanol), the mixtures were incubated in dark place at $25^{\circ} \mathrm{C}$ for $30 \mathrm{~min}$ ascorbic acid was used as standard antioxidant. The absorbance was recorded at $518 \mathrm{~nm}$. The percentage of scavenging activity of the test compounds was calculated according to the following formula:

\% Scavenging of $\mathrm{DPPH}=[(\mathrm{Ac}-\mathrm{As}) / \mathrm{Ac}] \mathrm{X} 100$

Where $A c$ is the absorbance of control (no sample or standard added to the DPPH solution) and As is the absorbance of the test. The tests were done in triplicate.

\section{Statistical Analysis}

Data were processed using SigmaPlot version 12.0 software. a Student's t-test was used to determine the statistical significance for unpaired observations. The $P$ values less than 0.01 considered as statistically significant.

\section{RESULTS AND DISCUSSION}

\section{Synthesis}

The target compounds $(4,5 \mathrm{a}-\mathrm{j})$ were synthesized via three steps synthetic route (Scheme 1). The starting materials have been chosen to get the structural requirements that make the new compounds as CA-4 analogues. The structure of compound 4 is the simplest in the series, it is considered as the precursor for the synthesis of compounds $5 \mathrm{a}-\mathrm{j}$, the modification of the structure is done by the attaching the aliphatic groups to the $-S$ atom (-S linker). In the first step, 3,4,5 trimethoxybenzohydrazide (1) was reacted with 4-methoxyphenyl isothiocyanate (2) to give the intermediate (3) which was isolated and then treated with $\mathrm{NaOH}$ to achieve the intramolecular cyclization giving the 1,2,4-triazole derivative 4. In the last step the hydrogen atom of the - $\mathrm{SH}$ group of compound 4 was substituted by different aliphatic substituents upon treatment with the appropriate alkyl halide in basic medium. Relatively good isolated yields (78 - $84 \%$ ) were obtained after purification by column chromatography.

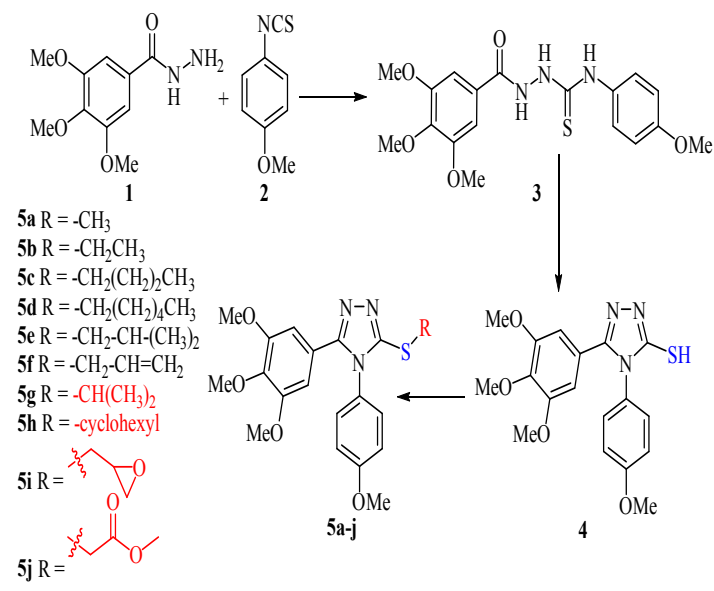

Scheme 1. Synthesis of $4,5 a-j$

\section{Anticancer Activity}

To evaluate the anticancer activity of compound 4 and study the effect of structure modification on the activity of compounds $5 \mathrm{a}-\mathrm{j}$, 
human colon cancer cell lines (SW480) were treated with two different concentrations $(10 \mu \mathrm{M}$ and $50 \mu \mathrm{M})$ of compounds $4,5 \mathrm{a}$-j for $48 \mathrm{~h}$ the cell growth inhibition was determined using crystal violet cytotoxicity assay, Fig. 1 shows the effect of the compound on the cells viability. The cell growth inhibition was calculated, Table 2 shows the obtained results, treatment of the cancer cell lines (SW480) with compound 4 which has free -SH group caused 6 and $10 \%$ cell growth inhibition at $10 \mu \mathrm{M}$ and $50 \mu \mathrm{M}$ respectively. Substitution of the $\mathrm{H}$ atom of the - $\mathrm{SH}$ group by methyl (compound 5a) caused a significant increase in the cytotoxic activity where the values of cell growth inhibition were found to be 50.4 and $77.4 \%$ at $10 \mu \mathrm{M}$ and $50 \mu \mathrm{M}$ respectively, on the other hand, the replacement of the $\mathrm{H}$ atom with primary aliphatic straight chains (n-ethyl, n-butyl and n-hexyl substituents in compounds $5 \mathrm{~b}, 5 \mathrm{c}$ and $5 \mathrm{~d}$ respectively)

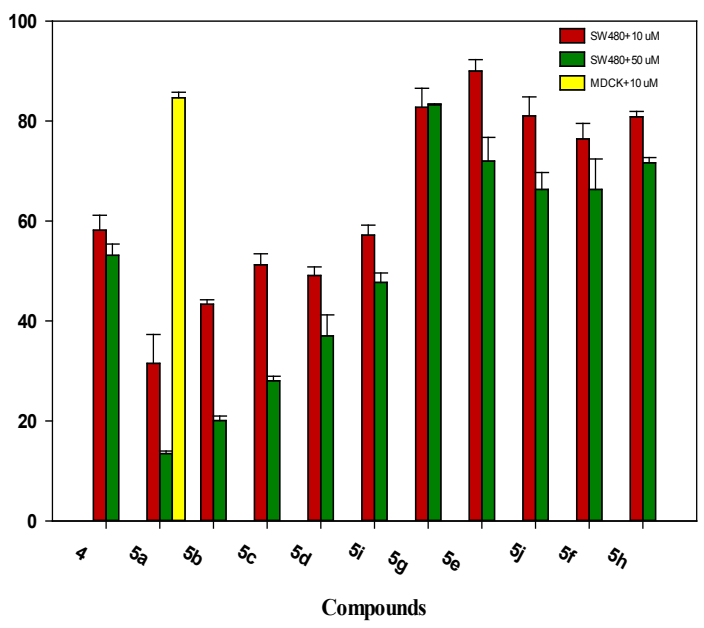

Fig. 1. Normalized cells viability percentage of SW480 cancer cell line and MDCK normal cell line at two different concentrations after incubation for $\mathbf{4 8}$ hours caused moderate improvement in the cytotoxic activity, within the results related to compounds $5 \mathrm{a}-\mathrm{d}$ it is clear that increasing the chain length decreases the activity, while no significant change in the cytotoxicity levels was observed with the other compounds where branched, olefinic, cyclic or ester groups are present as S-substituents in the structures of compounds $5 \mathrm{e}-\mathrm{j}$.

The results indicated that $5 \mathrm{a}$ is the most potent cytotoxic agent in the series, accordingly the next step was to evaluate the $\mathrm{IC}_{50}$ of compound $5 \mathrm{a}$ against the same cell line, the results showed that $10 \mu \mathrm{M}$ is the required concentration to cause $50 \%$ cancer cell lines (SW480) growth inhibition after incubation for 48 hours. Furthermore, to test the cytotoxicity of 5 a against normal cells, MDCK normal cell lines were treated with $5 \mathrm{a}$ at $10 \mu \mathrm{M}$ concentration $\left(\mathrm{IC}_{50}\right)$ for $48 \mathrm{~h}$ only $20 \%$ cell growth inhibition was observed, see Fig. 1 and Table 2.

\section{Antioxidant Activity}

The synthesized compounds (4, 5a-j) were subjected to DPPH assay to evaluate their free radical scavenging activity (antioxidant activity). The obtained results are shown in Table 3, compound 4 exhibited the highest antioxidant activity $(71 \%)$ when compared with ascorbic acid $(80 \%$ as the reference antioxidant), this could be attributed to the availability of free-SH group that makes the compound capable to accommodate the free radical and stabilize it by delocalization. Compounds 5e, 5f, 5i and 5j showed low to moderate antioxidant activity while the others (5a-d, $5 \mathrm{~g}$ and $5 \mathrm{~h}$ ) did not show any level of free radical scavenging activity.

Table 2: Cytotoxicity levels of $4,5 a-j$ against cancer and normal cells at different concentrations for $\mathbf{4 8}$ hours

\begin{tabular}{ccccc}
\hline Compound & $\begin{array}{c}\text { Percentage of cell } \\
\text { growth inhibition for SW480 } \\
50 \mu \mathrm{M}\end{array}$ & $\mathrm{IC}_{50}(\mu \mathrm{M})$ & $\begin{array}{c}\text { Percentage of cell growth inhibition } \\
\text { for MDCK normal cells at } \mathrm{IC}_{50}\end{array}$ \\
\hline 4 & 10 & 6 & -- & -- \\
$5 \mathrm{a}$ & 77.4 & 50.4 & 10 & 20 \\
$5 \mathrm{~b}$ & 61.1 & 26.2 & -- & -- \\
$5 \mathrm{c}$ & 52.2 & 18 & -- & -- \\
$5 \mathrm{~d}$ & 36.3 & 16 & -- & -- \\
$5 \mathrm{e}$ & 13 & 3 & -- & -- \\
$5 \mathrm{f}$ & 22 & 6.5 & -- & -- \\
$5 \mathrm{~g}$ & 11 & 1 & -- & -- \\
$5 \mathrm{~h}$ & 25 & 3 & -- & -- \\
$5 \mathrm{i}$ & 13 & 3.4 & -- & - \\
$5 \mathrm{j}$ & 20 & 3.7 & -- & \\
\hline
\end{tabular}


Table 3: Results of DPPH assay for antioxidant activity

\begin{tabular}{cc}
\hline Compound & $\begin{array}{r}\text { \% Scavenging of DPPH } \\
\text { free radical at } 50 \mu \mathrm{M}^{*}\end{array}$ \\
\hline ascorbic acid (standard) & 80 \\
4 & 71 \\
$5 e$ & 24 \\
$5 f$ & 10 \\
$5 \mathrm{i}$ & 45 \\
$5 j$ & 18 \\
\hline
\end{tabular}

${ }^{*}$ Compounds $5 \mathrm{a}-\mathrm{d}, 5 \mathrm{~g}$ and $5 \mathrm{~h}$ did not show any antioxidant activity.

\section{CONCLUSION}

Series of 3-mercapto-1,2,4-triazole derivatives have been designed as combretastatin A-4 analogues with different aliphatic substituents attached to the $S$ atom $(4,5 a-j)$. The target compounds were synthesized and characterized by different spectroscopic techniques. The cytotoxicity of 4, 5a-j was evaluated against colon cancer line (SW480), compound 5 a was found to be the most potent one and showed a kind of selectivity to cancer cells when subjected to evaluating its cytotoxicity against MDCK normal cell lines at $10 \mu \mathrm{M}$ concentration $\left(\mathrm{IC}_{50}\right)$. The results revealed $5 \mathrm{a}$ is a promising anticancer agent to be subjected for further studies. The antioxidant activity of $4,5 a-j$ was studied, the order of the activities was found to be 4, 5i, 5e, 5j, $5 f$.

\section{ACKNOWLEDGMENT}

The authors thank Al-Qasim Green University, Al-Mustansiyriah University and the University of Babylon for the financial support.

\section{Conflict of Interests}

The authors declare that there is no conflict of interests regarding the publication of this paper.

\section{REFERENCES}

1. Jemal A, Bray F, Center MM, Ferlay J, Ward E, Forman D. Global cancer statistics. $C A$ Cancer J Clin., 2011, 61, 69-90.

2. Alhurry AM, Rezaianzadeh A, RahimikazerooniS, Akool MA, Bahrami F, Shahidinia SS, Pourahmad M. Annals of Colorectal Research., 2017, 5, 3-4.

3. Rodrigues T, Reker D, Schneider P, Schneider G. Nature chemistry., 2016, 8, 531.

4. Cragg GM, Grothaus PG, Newman D J. J Nat Prod., 2014, 77, 703-23.

5. Pettit GR, Singh SB, Niven ML, Hamel E, Schmidt JM. J Nat Prod., 1987, 50, 119-31.

6. Burns RG., FEBS letters., 1992, 297, 205-8.

7. Kamal A, Bajee S, Nayak VL, Rao AV, Nagaraju B, Reddy CR, Sopanrao KJ, Alarifi A. Bioorg. Med. Chem. Lett., 2016, 26, 2957-64.

8. Patel, Vijay K, Harish R. Bioorg. Med. Chem. Lett., 2016, 26, 2115-2118.

9. Engdahl, Ashton J, Edith AT, Sarah EL, Taylor BE, Pamela SM, Craig N S. Organic letters., 2015, 17, 4546-4549.

10. Hsieh HP, Liou JP, Mahindroo N. Current pharmaceutical design., 2005, 11, 1655-77.

11. Romagnoli R, Baraldi PG, Prencipe F, Oliva P, Baraldi S, Tabrizi MA, Lopez-Cara LC, Ferla S, Brancale A, Hamel E, Ronca R. Scientific reports., 2016, 6, 26602.

12. Wang BL, Shi YX, Ma Y, Liu XH, Li YH, Song HB, Li BJ, Li ZM. Journal of agricultural and food chemistry., 2010, 58, 5515-22.

13. KKambojV,KVermaP,DhandaA, RanjanS. Central Nervous System Agents in Medicinal Chemistry Formerly Current Medicinal Chemistry-Central Nervous System Agents., 2015, 15,17-22.

14. Bhatnagar A, Sharma PK, Kumar N. Int J PharmTech Res., 2011, 3, 268-82.

15. Karabasanagouda T, Adhikari AV, Shetty NS. Eur. J. Med. Chem., 2007, 42, 521-9.

16. Sztanke K, Tuzimski T, Rzymowska J, Pasternak K, Kandefer-Szerszen M. Eur. J. Med. Chem., 2008, 43, 404-19.

17. Sarigol D, Uzgoren-Baran A, Tel BC, Somuncuoglu EI, Kazkayasi I, Ozadali-Sari K, Unsal-Tan O, Okay G, Ertan M, Tozkoparan B. Bioorg. \& Med. Chem., 2015, 23, 2518-28.

18. Küçükgüzel I, TatarE, Küçükgüzel SG, Rollas S, De Clercq E. Eur. J. Med. Chem., 2008, 43, 381-92.

19. El-Sherief HA, Youssif BG, Bukhari SN, AbdelAziz M, Abdel-Rahman HM. Bioorg. Chem., 2018, 76, 314-25.

20. Zhang Q, Peng Y, Wang XI, Keenan SM, Arora S, Welsh WJ. J. Med. Chem., 2007, 50, 749-54. 
21. Blanch NM, Chabot GG, Quentin L, Scherman D, Bourg S, Dauzonne D. Eur. J. Med. Chem., 2012, 54, 22-32.

22. Bogolubsky AV, Moroz YS, Mykhailiuk PK, Ostapchuk EN, Rudnichenko AV, Dmytriv YV, Bondar AN, Zaporozhets OA, Pipko SE, Doroschuk RA, Babichenko LN. ACS Combinatorial Science., 2015, 17, 348-54.

23. Azam, F. Therapeutic potential of free radical scavengers in neurological disorders. Handbook of Free radicals: Formation, Types and Effects. New York: Nova Publishers., 2010, 57-97.
24. Kurek-Górecka A, Rzepecka-Stojko A, Górecki M, Stojko J, Sosada M, SwierczekZieba G. Molecules., 2013, 19, 78-101.

25. Khan I, Ali S, Hameed S, Rama NH, Hussain MT, Wadood A, Uddin R, UI-Haq Z, Khan A, Ali S, Choudhary MI. Eur. J. Med. Chem., 2010, 45, 5200-7.

26. Bayoumi WA, Elsayed MA, Baraka HN, Abouzeid L. Archiv der Pharmazie., 2012, 345, 902-10.

27. Zhao PL, Duan AN, Zou M, Yang HK, You WW, Wu SG. Bioorg. \& Med. Chem letts., 2012, 22, 4471-4. 